\begin{tabular}{lcccr} 
T H E & A R C H I V E & O F & M E C H A N I C A L & E N G I N E E R I N G \\
\hline VOL. LVIII & 2011 & Number 1
\end{tabular}

10.2478/v10180-011-0008-4

Key words: LIDAR, laser, control, modal control

\author{
ALEXANDER VASILEVICH ZBRUTSKY *, MARYAM KAVESHGAR **
}

\title{
APPLICATION OF MODAL CONTROL FOR AUTOMOBILE CRUISE CONTROL
}

\begin{abstract}
A complete system of a Laser Radar is described in this paper. One explains the principles of the laser and all additional devices used in this system in order to obtain a compact and eye-safe system. The principle and realization of algorithms for controlling the cruise and speed of the vehicle are described. By applying modal control, and choosing the optimal mode for reducing the speed, one derives the system equation and determines its coefficients. Finally, the paper presents simulations of the laser scanning system, the modal control system and the behavior of the system affected by different errors and disturbances. The effects of instrumental errors are defined and simulation is performed illustrating how such a control system is influenced by internal and external disturbances.
\end{abstract}

\section{Introduction}

The intelligent transportation system is one of the highly pursued research topics in different fields of science and industry. Nowadays, the increasing number of vehicles in cities, and the consequent increase in number of collisions, make us think about a precise and fast responding system to solve some of these problems.

Until now, there have been many research groups that have developed anti-collision systems like ACC or Adaptive Cruise Control [1-4]. Such systems are either equipped with night vision cameras, or are just able to adapt the speed to the vehicle ahead and prevent colliding into the obstacle. More updated systems are equipped with several assisting systems, such as GPS, or digital cameras which would make their algorithms too complicated to be used in industrial or urban areas. Then, this paper provides a solution to

* Dr.Tech. Sc., National Technical University, Kiev Polytechnic Institute Kiev, Ukraine

** National Technical University, Kiev Polytechnic Institute, Kiev, Ukraine; e-mail: mkavesh@yahoo.com 
these design defects. The goals of this article are to develop an algorithm for a proper control system to control the speed and avoid collisions using a compact eye-safe laser system as an eye for detecting the obstacles.

\section{Scanning laser system}

A proper system for collecting the information from the surrounding environment is one of the important requirements to design an intelligent system. Anti-collision designs, currently available on the industrial market, usually take advantage of night vision cameras or laser beams with no scanning system. Both of them are characterized by poor vision in unfavorable situations and changing weather conditions.

In the designed system presented in this paper, a scanning infrared laser block (Scanning LIDAR) plays the role of a detecting and ranging system.

An infrared laser beam, lased from a diode-pumped solid-state $\mathrm{Nd}$ YAG laser, is used to scan the front area of a moving vehicle. The laser is q-switched by an electro-optical q-switch to provide perfect narrow pulses.

Since the beam wavelength of Nd-YAG laser is $1.064 \mu \mathrm{m}$, it is not eyesafe. To solve this problem, an OPO - Optimal Parametric Oscillator - is mounted in the structure. The nonlinear properties of the crystal used in the OPO enable shifting the wavelength of the passing laser beam pulses from $1.064 \mu \mathrm{m}$ to $1.54 \mu \mathrm{m}$, the latter being an eye-safe wavelength for the human eye. The main signal, of $1.54 \mu \mathrm{m}$ wavelength would be the beam that scans the area, and the idler signal of $3.4 \mu \mathrm{m}$ wavelength can be used for further applications to make the system more accurate.

A Galilean telescope is used as a beam expander to reduce the scattering effect. The beam expander is followed by a scanner. This mechanism is composed of two galvanometers. A flat mirror is placed on each of their rotor shafts.

The scanning mirrors are a part of the control contour. The position of the beam lased to any point of the surrounding environment is sent to the control system, which will be described below.

To collect the information about the surrounding area, a laser beam is sent to each point by the scanner. Assume a point $\left(\mathrm{x}_{i}, \mathrm{y}_{j}\right)$. When the scanner is pointing the laser beam at this point, the information about the elevation and azimuth of $\left(\mathrm{x}_{i}, \mathrm{y}_{j}\right)$ is sent to the receiving block of the system. Meanwhile, the laser beam reaches the target, and reflects from its surface.

In the receiver block, a NFOV (Narrow Field of View) lens is tilted towards the direction known from the scanner galvanometers, which capture the reflected laser pulse. The laser passes through a narrow-band optical filter 
and reaches the photodiode, an APD (Avalanche Photo Diode), designed for near infra-red spectrum of light.

Receiving the laser pulses from $\left(\mathrm{x}_{i}, \mathrm{y}_{j}\right)$, the system determines the distance from the obstacle using TOF (Time of Flight) method. The material reflecting the laser pulses can also be recognized. This is achieved by comparing the power of pulses generated by the laser block with the power of the received pulses [5].

This way, application of both TOF method and impulse power measuring provides enough information about the characteristic of the point $\left(\mathrm{x}_{i}, \mathrm{y}_{j}\right)$.

The whole area in front of the vehicle can be divided into many points, called the pixels. Each pixel can be described by information consisting of azimuth, elevation, distance and reflectivity coefficient. After a complete scan of the area, a pattern can be formed to show the driver the road, the road side and any obstacle existing on them.

Such a scanning can be performed periodically to give the driver a realtime image of the road in front of the vehicle.

Assuming that, at the beginning of the movement, the system has performed a control scan of the road, one can calculate the reflectivity coefficient of the road and road side. It is understandable that anything that does not belong to these two groups will appear as an obstacle. In order to do so, an algorithm is defined to scan the controlling line. This line includes 11 points at the lowest level of the scanner: 3 points right in front of the car, 4 at the side-ends of the scanning line and 4 in between. In this way, every time before moving, the updated information about the reflectivity of the road can be obtained.

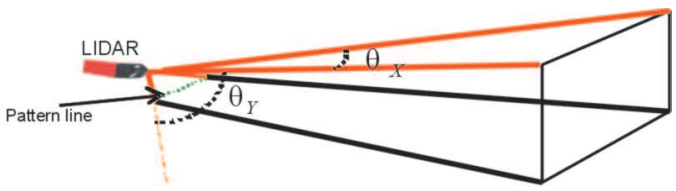

Fig. 1. Scanning area and the pattern line

From here onwards, reflectivity information of each and every point scanned by the system will be compared with the data from the controlling line.

A computer program was written in DELPHI to simulate the whole scanning and displaying system [5]. The algorithm used in this program takes advantages of 2 matrices from the scanned points. Matrix D contains the information about distances, and matrix $\mathrm{R}$ refers to reflectivity coefficients. In the program, the matrices are assumed to be $100 \times 100$. Each element of the matrix represents one position of the scanner, for instance $\mathrm{G}\left(\mathrm{x}_{i}, \mathrm{y}_{j}\right)$. 
The calculated reflectivity from each point is compared with three groups of reflectivity, defined by the controlling line. Depending on the results, three different colors separate these scanned points from each other. Blue color represents the road, green - the roadside, and everything except these two is displayed in red color.

The brightness of the colors indicates the distance. The greater the distance from the system, the darker the color. If the transmitted impulse is not received by the APD, the respective point is classified as unidentified and is displayed in white color.

A yellow indicator in the display shows the way ahead. A critical distance is defined for the system. The obstacles at a closer distance from the vehicle would blink on the display. This means that, if they lie on the path ahead, the controlling system takes a decision and chooses the right algorithm to avoid them. Every obstacle is separated by an outline from the environment around it. The data about each obstacle, such as its distance from the vehicle and its coordinates are displayed above it.

\section{The algorithm and synthesizing of control systems}

After recognizing the objects on the road, the control system has to make a decision whether the vehicle should change its speed and/or change its course and how it should be performed. Two different algorithms are suggested to reduce the speed in various situations that might happen during the movement. One possibility is using the control of throttle valve angle and the other one to control the pressure of brake system. Knowing the angle of the slope and the distance from the object, the system can choose one of these algorithms to provide the safest and most comfortable conditions for the passengers. Meanwhile, the safety parameters of the system are checked by sensors to keep the vehicle in a stable situation. The parameters of safety are the difference between angular velocities of the wheels on the same axle and the difference in the angular velocity of two different axles. This way, while steering, the automobile would not slide on the road [6].

Since the information about the state vector is incomplete, modal control has been used to synthesize an ideal control system and bring the roots of the closed loop system to the positions which are known in advance. To achieve this goal, the method of standard coefficients of a characteristic equation has been used.

Knowing the transfer functions of the plant $W_{p}$, the regulator $W_{r}$ and the feedback $W_{f b}$, and choosing the functional, the criteria for minimum control module error and maximum performance speed, we can choose a proper graph from Fig.2 to reduce the speed [7]. 


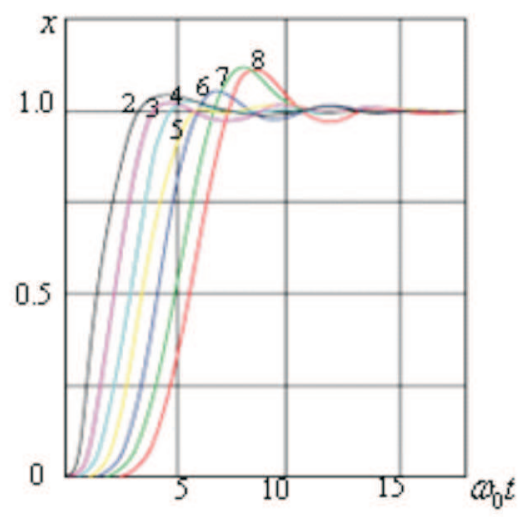

Fig. 2. Step response of the system with functional I

Two different conditions are considered to determine the standard coefficients. First, the inertia of the measurement devices is included in the transfer function of the closed loop system. Secondly, the closed loop transfer function is assumed without considering the inertia of the measurement devices.

\section{A. Determining the control system factors when inertia is included in the plant}

The inertia of the measuring device, the speedometer, is assumed as $W_{i n}=\frac{1}{T s+1}$, where $T=0.2$. If the inertia is included into the whole system before calculating the transfer functions of the regulator and the feedback $W_{r}=\frac{W_{r}^{n}}{W_{r}^{d n}}, W_{f b}=\frac{W_{f b}^{n}}{W_{f b}^{d n}}$, the whole system has the following transfer function where $W_{p}=\frac{W_{p}^{n}}{W_{p}^{d n}}$ is the transfer function of the plant:

$$
\begin{aligned}
\varphi_{v}^{u} & =\frac{K_{\text {eng }} W_{r} W_{p}}{1+K_{\text {eng }} W_{r} W_{f b} W_{\text {in }} W_{p}}= \\
& =\frac{K_{\text {eng }} W_{r}^{n} W_{p}^{n} W_{f b}^{d n}}{W_{p}^{d n} W_{f b}^{d n} W_{i n}^{d n} W_{r}^{d n}+K_{\text {eng }} W_{r}^{n} W_{p}^{n} W_{f b}^{n} W_{i n}^{n}}
\end{aligned}
$$

where:

$$
W_{r}=\frac{T_{r 1} s+T_{r 2}}{s} ; \quad W_{f b}=\frac{T_{f b 1} s+T_{f b 2}}{T_{f b 3} s+1} ; \quad W_{p}=\frac{K_{0}}{T s+1}
$$


Due to the $4^{\text {th }}$ order of the denominator in the transfer function of system, it is necessary to choose the $4^{\text {th }}$ order of the polynomial from the optimizing functional I [7].

$$
\begin{aligned}
& W_{p}^{d n} W_{f b}^{d n} W_{i n}^{d n} W_{r}^{d n}+K_{\text {eng }} W_{r}^{n} W_{p}^{n} W_{f b}^{n} W_{i n}^{n}= \\
& =s^{4}+2.1 \omega_{0} s^{3}+3.4 \omega_{0}^{2} s^{2}+2.7 \omega_{0}^{2} s+\omega_{0}^{4}
\end{aligned}
$$

After calculating the coefficients of regulator and feedback, the system is simulated in the SIMULINK. The reaction of the system to a step input with the amplitude of $20 \mathrm{~m} / \mathrm{s}$ is shown in Fig. 3 .

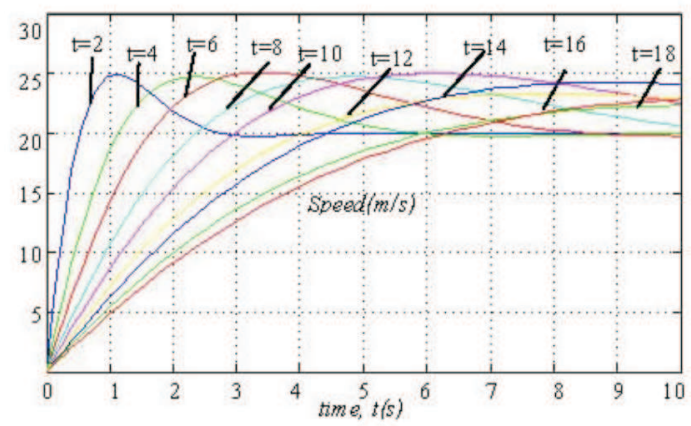

Fig. 3. Step response of the closed loop system for different rise times, from left to right $\mathrm{t}=2,4,6,8,10,12,14,16,18 \mathrm{sec}$, when step input is $20 \mathrm{~m} / \mathrm{s}$

The output of the system shows a big overshoot and a long rise time. In the next step, the control system is defined without including the inertia.

\section{B. Determining the control system factors without considering the inertia}

Looking at the graphs of the system, optimized by I, responding to a step input source, we have chosen a third order polynomial to optimize the system. The chosen equation would provide a minimal overshoot, a good rise time and less oscillation compared to other solutions.

$$
\begin{gathered}
W_{r}=\frac{T_{r 1} s+T_{r 2}}{s} ; \quad W_{f b}=\frac{T_{f b 1} s+T_{f b 2}}{T_{f b 3} s+1} ; \quad W_{p}=\frac{K_{0}}{T s+1} \\
W_{p}^{d e n} W_{f b}^{d e n} W_{r}^{d e n}+K_{\text {eng }} W_{r}^{n} W_{p}^{n} W_{f b}^{n}= \\
=s^{3}+1.75 \omega_{0} s^{2}+2.15 \omega_{0}^{2} s+\omega_{0}^{3}
\end{gathered}
$$


The system is simulated in the SIMULINK and MATLAB environment. The results indicate that the designed control blocks and their chosen coefficients are quite close to what was expected (Fig.4). The step response is simulated for different systems with different rise times.

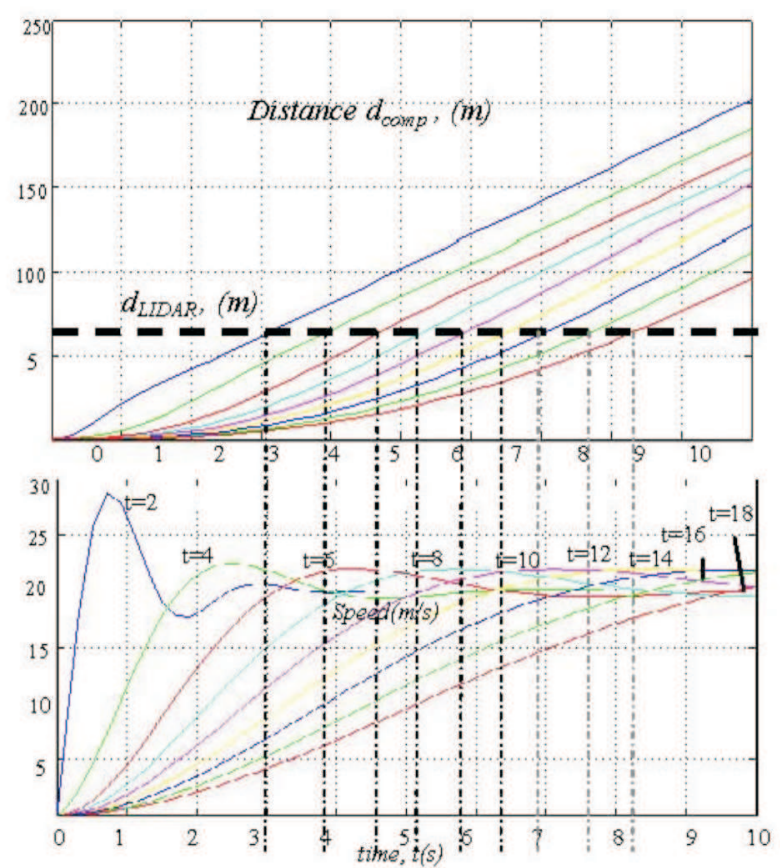

Fig. 4. Step response of the closed loop system for different rise times, from left to right $\mathrm{t}=2,4,6,8,10,12,14,16,18 \mathrm{sec}$, and the distance passed by the vehicle at this time, when step input is $20 \mathrm{~m} / \mathrm{s}$

Two steps for reducing the speed are presented below, the first - by controlling the throttle valve, and the second - by activating the brake [5].

If the vehicle is at a sufficiently long distance from the obstacle $\left(\mathrm{d}_{\text {LIDAR }}>\mathrm{d}_{\text {comp }}\right)$, or the angle of the road slope is " 0 "'or " +", usually a change in the angle of the throttle valve is enough for controlling the speed, but if the object is too close $\left(\mathrm{d}_{\text {LIDAR }} \leqslant \mathrm{d}_{\text {comp }}\right)$ or the slope angle is "-", then the braking system must be activated.

In this system, the speed of the vehicle is not adapted to the speed of the object, instead the control system maintains such conditions which allow the vehicle to take action and change its course of movement. The two algorithms mentioned above take action when the speed must be reduced to the value calculated for safe steering. 
When a vehicle is going to turn, it must move with an appropriate speed, according to its characteristics and the turning radius.

This speed is determined by the data received from the LIDAR system and the sensors. Knowing the distance, dimensions of the obstacle, speed and the weight of the vehicle, the control system calculates the final speed to which it has to reduce vehicle's speed to be prepared for steering.

\section{System accuracy and its response to instrumental errors and disturbances}

Like in any other case of designed system, we should know the system reaction to any type of error and disturbance that can occur or appear in the system.

Considering that the range finding uses the TOF method, one can notice that an error can be caused by a change in the speed of light, and also by some instrumental errors appearing in the digital system of the counter. Application of digital instruments and elements in the LIDAR system would reduce the error of range finding to $0.6-1 \mathrm{~m}$ [8].

Rather than the accuracy of the detecting system, one should evaluate the effect of disturbances and errors in the speed control system. In order to do so, the control system was simulated and its response to different influences has been studied.

As an example, white noise was added to the $3^{\text {rd }}$ order system with $\mathrm{t}=6$ from Fig. 4. The effect of white noise with $10 \%$ RMSD on the closed loop system is shown in Fig. 5.

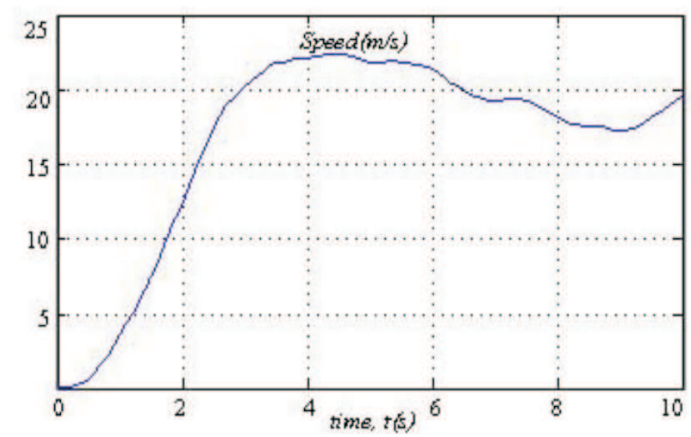

Fig. 5. Step response of the $3^{\text {rd }}$ order system with white noise effect

The added noise resulted in a small distortion in the output of the control system. 
In the control system realized by a feedback block consisting of measuring sensors and shaping filters some distortions may appear due to dynamic behavior of the sensors and filters (inertia) and errors of the measuring instruments.

In Fig. 6, there is shown the effect of the inertia and the error of all measuring devices calculated for the $3^{\text {rd }}$ order system, taking into account real transfer functions of system elements.

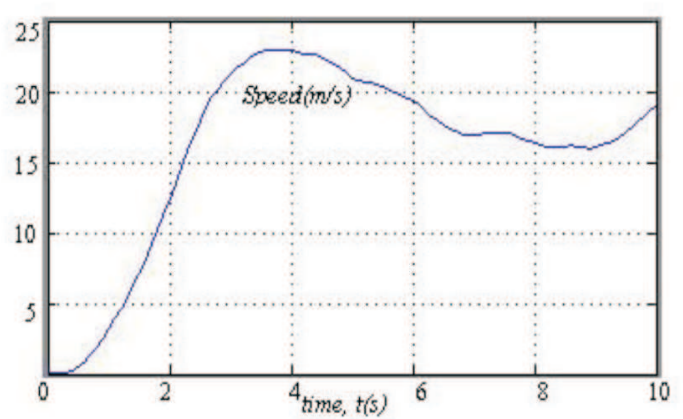

Fig. 6. Step response of the system with white noise, inertia and error of measuring instruments

It can be seen that the system reaction to inertia of the odometer is demonstrated as a higher overshoot in the response.

In addition, the reaction of the $4^{\text {th }}$ order system to white noise and instrumental error with 10\% RMSD is shown in Fig. 7. To show the effect of white noise, the system with rise time of $t=6$ from Fig. 3 is selected.

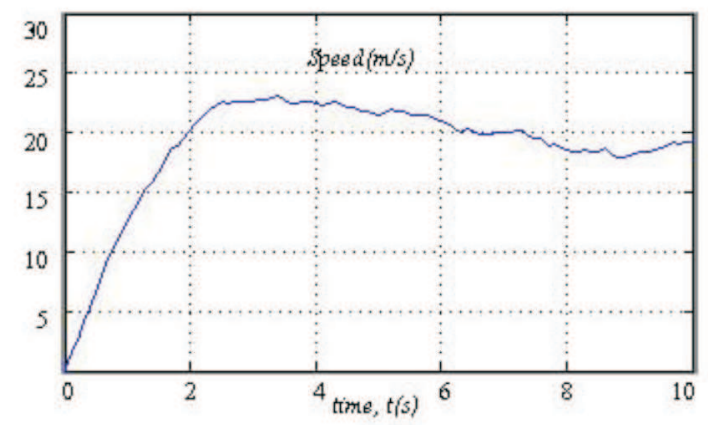

Fig. 7. Step response of the $4^{\text {th }}$ order system to white noise and instrumental error

As a result, it is shown that $4^{\text {th }}$ order system in Fig. 7 is responding to a step input with a smaller overshoot and disturbances than those in Fig. 6. 


\section{Stability of system}

The stability of the whole system is examined by Root Locus and the Bode diagram. The designed systems are simulated in MATLAB to see if the desired goals are achieved [9].

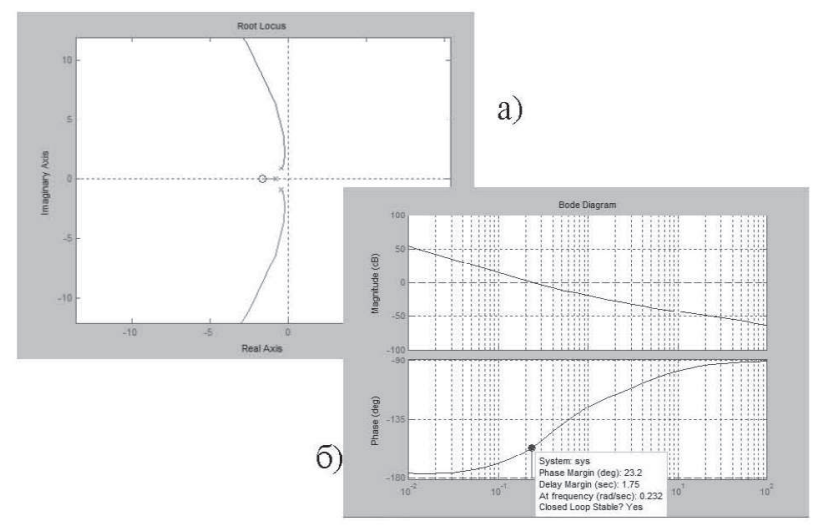

Fig. 8. a) Root Locus and b) Bode diagram of the system with $n=3$ and $t=6$

The simulation shows that the closed loop system is stable. The open loop system crosses the $0 \mathrm{~dB}$ at a frequency of $0.232 \mathrm{rad} / \mathrm{s}$ and the phase margin for this point is $23.2 \mathrm{deg}$ (Fig. 8).

The coefficients of the control blocks are determined, using the denominator of the transfer function while the numerator of the transfer function is assumed equal to 1 . Then, by changing the coefficients of the numerator in the feedback and regulator functions one can introduce some changes in step response of the whole system. In addition, the calculated parameters for the control system could be changed during the application with the help of the standard coefficients method. Therefore, we have simulated the response of the controlled system assuming the change of coefficients with a 50\% tolerance. The results show that the changes within these tolerances would never bring the system to instability. Moreover it is noticeable that an increase in $\mathrm{T}_{r 2}$ would result in a smaller overshoot in the response of the closed loop system, and yet the system remains stable, with a phase margin of $34.6 \mathrm{deg}$ (Fig. 9).

By changing this coefficient, we can achieve an optimal response. An increase in the coefficient $\mathrm{T}_{r 2}$, will result in a response with a smaller overshoot and an adequate rise time. 


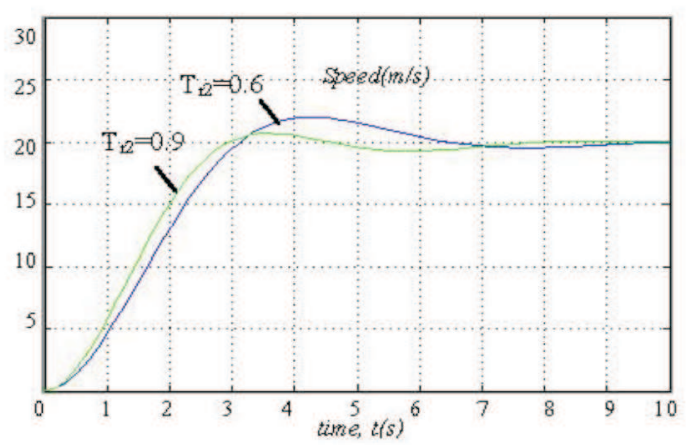

Fig. 9. Step response of the system with $\mathrm{t}=6$ when $\mathrm{T}_{r 2}=0.6$, and $\mathrm{T}_{r 2}=0.9$

\section{Conclusion}

In this paper, we presented a transmitter and receiver system for a LIDAR system. Using the TOF method, we could determine the distance between the vehicle and any object on its path. The model of the system is designed in DELPHI.

The Suggested algorithms make the system capable of controlling the speed and prepare the vehicle for safely changing its course. Depending on the distance of the vehicle to the obstacle, and taking into account the slope angle of the road, the system decides whether the throttle valve or brake control is to be chosen. Meanwhile, the safety parameters of the whole system are controlled.

An optimized control is defined for the system by using modal control of programming control methods. The step response of the system is simulated in the SIMULINK for different rise times. The effect of disturbances and errors in the system is investigated. The change of parameters, calculated by the system of standard coefficients can reduce the overshoot in the system step response.

The stability of the closed loop system is examined by applying Root Locus criteria. $0 \mathrm{~dB}$ cross frequency and the phase margin of the system is determined using a Bode diagram of the open-loop system.

Manuscript received by Editorial Board, November 29, 2010;

final version, February 28, 2011.

\section{REFERENCES}

[1] Автомобильный справочник: пер. с анг. - 2-е изд., перераб. и доп. - М.: ЗАО "КЖИ" за рулем, 2004. - 992 с.

[2] U. Hofmann, A. Rieder and E.D. Dickmanns. "Radar and vision data fusion for hybrid adaptive cruise control on highways," Volume 14, Number 1 / April, 2003 Pages42-49. 
[3] Rainer Möbus, MatoBaotic and Manfred Morari. "Multi-object Adaptive Cruise Control," Springer Berlin / Heidelberg Volume 2623/2003pp 359-374.

[4] Vahidi A, Eskandarian A., "Research advances in intelligent collision avoidance and adaptive cruise control," Intelligent Transportation Systems, IEEE Transactions on Volume: 4, Issue: 3 On page(s): 143-153.

[5] Kaveshgar M. "Application of scanning laser system for automobile handling," наукові Вітті, КИІВ, 2004-4006, 6(38), 79.

[6] В.П. Сахно, Г. Б. Безбородова, М. М. Маяк, С.М. Шарай, “Автомобілі: тягобо-швидкісні властивості та палива єкономічність”, /Навч. Посібник/. К:Вво «КВШ» 2004, 174 Сторінки. Іл. 15. Табл. 19. Бібліограф. 30. Назв. 30.

[7] Кузовков Н. Т. Системы стабилизации летательных аппаратов (баллистических и зенитных ракет): учеб. пособие для вузов. - М.: Высщ. школа, 1976.-304 c.

[8] МалашИн: Малашин М. С. Камински и Р. П., Борисов Ю. Б. "Основы проектирования лазерных локационных систем,": Учеб. Пособие для радиотехн. Спец. Вузов. - М.: Высщ. Школа, 1983. - 207 с., ил.

[9] Ogata K. Modern Control Engineering, 3-d ed.-Prentice hall, PTR.- 1997.-250p.

\section{Zastosowanie sterowania modalnego do sterowania jazda samochodu}

\section{Streszczenie}

W artykule opisano kompletny system radaru laserowego. Wyjaśniono zasady działania lasera i wszystkich dodatkowych elementów zastosowanych po to, by uzyskać system o małych rozmiarach i bezpieczny dla wzroku. Opisano zasadę i realizację algorytmów sterowania przebiegiem i prędkością pojazdu. Stosując sterownie modalne i wybierając optymalny sposób redukcji prędkości wyprowadzono układ równań i wyznaczono ich współczynniki. W końcowej części zaprezentowano symulację laserowego systemu skanowania, systemu sterowania modalnego i działania systemu w obecności błędów i zakłóceń. Zdefiniowano skutki błędów aparaturowych i przeprowadzono symulację ilustrującą wpływ wewnętrznych i zewnętrznych zakłóceń na działanie takiego systemu. 